ALCHEMY Jurnal Penelitian Kimia

Laman resmi: https://jurnal.uns.ac.id/alchemy

\title{
Studi In Silico Senyawa 1,4-Naphthalenedione-2-Ethyl-3-Hydroxy sebagai Antiinflamasi dan Antikanker Payudara
}

\author{
Richa Mardianingrum ${ }^{a^{*}}$, Kamiel Roesman Bachtiar ${ }^{\mathrm{a}}$, Susanti Susanti ${ }^{\mathrm{a}}$, Aas Nuraisah ${ }^{\mathrm{a}}$, Ruswanto \\ Ruswanto $^{\text {b }}$ \\ a Prodi Farmasi, FIK, Universitas Perjuangan, Jl. Peta 177 Tasikmalaya, Indonesia 46115 \\ bProdi Farmasi, STIKes Bakti Tunas Husada, Jl. Cilolohan No. 36 Kota Tasikmalaya 46115 \\ *Corresponding author: ruswanto@stikes-bth.ac.id \\ DOI: 10.20961/alchemy.17.1.43979.83-95
}

Received 25 August 2021, Accepted 25 February 2021, Published 08 March 2021

Kata kunci:

$1,4-$

naphthalenedione-

2-ethyl-3-hydroxy; antiinflamasi;

antikanker payudara; bangle; in silico.

Keywords:

\section{1,4-}

naphthalenedione2-ethyl-3-hydroxy; anti-inflammatory; anti-breast cancer; bangle; in silico.
ABSTRAK. Inflamasi merupakan suatu respon dari tubuh terhadap adanya cedera maupun infeksi yang ditandai dengan timbulnya kemerahan, demam, bengkak, nyeri dan hilangnya fungsi. Inflamasi berkontribusi terhadap ketidakseimbangan sekresi sitokin yang akan menghambat terjadinya apoptosis pada sel kanker sehingga menyebabkan hiperproliferasi sel. Kanker payudara merupakan salah satu penyakit kanker dengan prevalensi tertinggi di urutan ke dua di dunia. Penelitian terdahulu melaporkan pemberian minyak atsiri rimpang bangle (Zingiber purpureum Roxb.) secara topikal mampu memberikan penghambatan inflamasi yang lebih tinggi daripada triamcinolone, namun spesifik senyawa yang berpotensinya belum diketahui. Tujuan dari penelitian ini, yakni mencari senyawa aktif hasil analisis GCMS minyak atsiri rimpang bangle yang berpotensi sebagai antiinflamasi dan antikanker payudara secara in silico. Metode yang digunakan berupa screening Lipinski's Rule of Five, farmakokinetika dan toksisitas senyawa hasil analisis GC-MS, serta penambatan molekul dan dinamika molekular. Hasil screening dan simulasi penambatan molekul menunjukkan bahwa senyawa 1,4-naphthalenedione-2ethyl-3-hydroxy dapat berikatan dengan reseptor COX-1 (antiinflamasi), dan $\mathrm{hER} \alpha$ (antikanker payudara), namun lebih selektif terhadap reseptor COX-1 dengan nilai energi bebas $(\Delta \mathrm{G})$ yang lebih kecil yakni sebesar $-7,20 \mathrm{kkal} / \mathrm{mol}$, dibandingkan dengan interaksinya terhadap reseptor Er $\alpha$ yang bernilai $-6,00$ $\mathrm{kkal} / \mathrm{mol}$. Hasil simulasi dinamika molekular menggunakan metode kalkulasi MM-GBSA menunjukkan bahwa kompleks (1,4-naphthalenedione-2-ethyl-3-hydroxy)-(COX-1) memiliki nilai $\Delta \mathrm{G}_{\mathrm{TO} \text { TAL }}$ sebesar $-24,22 \mathrm{kkal} / \mathrm{mol}$. Nilai ini lebih kecil dibandingkan dengan $\Delta \mathrm{G}$ TотаL kompleks (1,4-naphthalenedione-2ethyl-3-hydroxy)-(hEr $\alpha$ ) sebesar $-8,92 \mathrm{kkal} / \mathrm{mol})$. Hal ini menunjukkan bahwa tingkat afinitas 1,4naphthalenedione-2-ethyl-3-hydroxy terhadap COX-1 diprediksi lebih baik dan lebih poten sebagai antiinflamasi dibandingkan sebagai antikanker payudara.

ABSTRACT. In Silico Study of 1,4-Naphthalenedione-2-Ethyl-3-Hydroxy Compounds as Antiinflamation dan Breast Anticancer. Inflammation is a response from the body to injury or infection which is characterized by redness, fever, swelling, pain, and loss of function. Inflammation contributes to the imbalance of cytokine secretion which will inhibit apoptosis in cancer cells, causing cell hyperproliferation. Breast cancer is one of the cancer diseases with the second-highest prevalence in the world. The pioneering works reported that topical application of Bangle (Zingiber purpureum Roxb.) was able to provide a higher inhibition of inflammation than triamcinolone, however, the specific potential of the compound was unknown. The purpose of this study is to find active compounds that have the potential to be anti-inflammatory and anti-cancer in the breast using in silico approach. The methods used are screening Lipinski's Rule of Five, pharmacokinetics and toxicity of compounds from GC-MS analysis and molecular docking, and molecular dynamics. The screening and molecular docking simulation results showed that the compound 1,4-naphthalenedione-2-ethyl-3-hydroxy can bind to COX-1 (antiinflammatory), and ER $\alpha$ (Estrogen Reseptor $\alpha$ ), but was more selective towards COX-1 receptor with a binding affinity $(\Delta \mathrm{G})-7.20 \mathrm{kcal} / \mathrm{mol}$, compare to its interaction with ER $\alpha$ which is $-6.00 \mathrm{kcal} / \mathrm{mol}$. The results of molecular dynamics simulation using the MM-GBSA calculation method show that the complex (1,4-naphthalenedione-2-ethyl-3-hydroxy)-(COX-1) has a value of $\Delta \mathrm{G}_{\text {TотAL }}$ of $\left.-24.22 \mathrm{kcal} / \mathrm{mol}\right)$. This value is smaller than $\Delta \mathrm{G}$ тотаL of the complex (1,4-naphthalenedione-2-ethyl-3-hydroxy)-(hEr $\alpha$ ) of -8.92 $\mathrm{kcal} / \mathrm{mol}$. The results indicate that the affinity level of 1,4-naphthalenedione-2-ethyl-3-hydroxy to COX1 was predicted to be better and more potent as an anti-inflammatory than as an anti-breast cancer. 


\section{PENDAHULUAN}

Inflamasi merupakan suatu respon dari tubuh terhadap adanya cedera maupun infeksi (Dhyantari, 2015). Adanya proses inflamasi ditandai dengan timbulnya kemerahan (rubor), suhu yang meningkat (calor), bengkak (tumor), nyeri (dolor) dan hilangnya fungsi (functio laesa) (Supriyatna et al., 2015). Inflamasi berkontribusi terhadap ketidakseimbangan sekresi sitokin yang akan menghambat terjadinya apoptosis pada sel kanker sehingga proliferasi sel meningkat dengan cepat (Sobolewski et al., 2010). Salah satu sel kanker bisa tumbuh pada payudara. Kanker payudara merupakan salah satu penyakit kanker dengan prevalensi tertinggi di urutan kedua di dunia, terhitung 11,6\% dari semua kasus akibat kanker (Bray et al., 2018).

Pada umumnya pengobatan yang dipakai untuk mengatasi terjadinya inflamasi adalah ibuprofen dan kanker payudara adalah tamoxifen, kedua obat tersebut disebut obat modern yang dapat membawa resiko toksisitas untuk penggunaan yang berkepanjangan, oleh karena itu, masyarakat cenderung memilih menggunakan obat tradisional untuk kebutuhan terapi yang memiliki banyak khasiat dan efek samping yang relatif rendah (Ningsih, 2016). Beberapa tanaman mengandung senyawa bioaktif yang berkhasiat sebagai obat, salah satunya adalah minyak atsiri.

Minyak atsiri merupakan salah satu senyawa metabolit sekunder yang dihasilkan oleh tanaman yang memiliki bau atau aroma khas. Berdasarkan penelitian, minyak atsiri mempunyai beberapa aktivitas, diantaranya sebagai antimikroba (Bassolé and Juliani, 2012), antikanker (Bayala et al., 2014), antiinflamasi dan antioksidan (Liju et al., 2011). Salah satu tanaman yang mengandung minyak atsiri adalah bangle (Zingiber purpureum Roxb.). Komponen utama minyak atsiri rimpang bangle terdiri atas sabinene (48,1\%), terpinen-4-ol $(25,1 \%)$, c-terpinene (6,7\%), $\alpha$-terpinene (4,3\%), $\beta$-thujene (3,4\%), dan $\alpha$-phellandrene (2,7\%) (Wang et al., 2015).

Menurut Thaweboon et al. (2018) pemberian minyak atsiri rimpang bangle secara topikal mampu memberikan penghambatan inflamasi yang lebih tinggi dari pada triamcinolone pada waktu 30 dan 60 menit, sedangkan penelitian minyak atsiri rimpang bangle (Zingiber purpureum Roxb.) terhadap aktivitas antikanker payudara belum dilakukan, oleh karena itu diperlukan upaya pengembangan obat dari minyak atsiri rimpang bangle sebagai antikanker payudara.

Berdasarkan uraian diatas, potensi aktivitas antiinflamasi dan antikanker payudara pada bangle menarik untuk dipelajari. Oleh karena itu, penelitian ini memaparkan hasil analisis kandungan senyawa minyak atsiri bangle dengan metode Gas Cromatography Mass Spectrometry (GC-MS). Analisis lanjut juga dilakukan melalui metode komputasi (in silico) secara penambatan molekul dan dinamika molekular terhadap reseptor cyclooxygenase-1 (COX-1) dengan ibuprofen sebagai kontrol positif pada screening antiinflamasi dan 4hidroksitamoxifen (4-OHT) sebagai kontrol positif pada screening antikanker payudara.

\section{METODE PENELITIAN}

\section{Preparasi Ligan dan Protein}

Reseptor yang digunakan pada penelitian ini diunduh dari situs Protein Data Bank (PDB) yang kemudian dipisahkan dengan ligan dan air serta ditambahkan muatan (Dermawan et al., 2019). Ligan dari hasil analisis GCMS minyak atsiri rimpang bangle (Zingiber purpureum Roxb.) digambar dengan program ChemDraw Ultra 8.0, kemudian dilakukan protonasi pada $\mathrm{pH}$ 7,4 disesuaikan dengan $\mathrm{pH}$ tubuh dengan program MarvinSketch, kemudian dilakukan comformational search (Ruswanto, 2015).

\section{Prediksi Aspek Farmakokinetika dan Toksisitas}

Prediksi Aspek Farmakokinetika dan Toksisitas dilakukan menggunakan program PreADMET diakses di http://preadmet.bmdrc.org/ (Mardianingrum et al., 2020).

\section{Screening Ligan Based Drugs Likeness (Drug Scan)}

Pengamatan obat dilakukan pada semua ligan dengan memperhatikan aturan obat yang baik (Lipinski's Rule of Five) yaitu meliputi berat molekul $<500 \mathrm{~g} / \mathrm{mol}$, lipofilitas $<5$, donor ikatan hidrogen $<5$, akseptor ikatan hidrogen $<10$, refractory molar antara 40 - 130. Parameter aturan Lipinski's Rule of Five dapat ditentukan dengan software MarvinSketch (Tambunan et al., 2012). 


\section{Validasi Metode Penambatan Molekul}

Tahapan validasi dilakukan dengan menambatkan ulang ligan terhadap reseptornya yang telah dipisahkan terlebih dahulu. Metode docking dikatakan baik jika memiliki nilai Root Mean Square Deviation (RMSD) yang dihasilkan $\leq 2 \AA$ (Puratchikody et al., 2016).

\section{Simulasi Penambatan Molekul}

Proses penambatan molekul dilakukan menggunakan software AutoDockTools 1.5.6 dengan memasukkan nilai parameter Autogrid. Penambahan muatan pada ligan menggunakan Gasteiger, sedangkan hitungan algoritmanya menggunakan Lamarckian Genetic (Trott et al., 2010; Fuhrmann et al., 2010) dengan menjalankan sebanyak 100 kali. Autodock 4.2 digunakan pada saat proses simulasi penambatan molekul. Analisis hasil penambatan molekul dilakukan dengan memilih konformasi ligan yang memiliki energi ikatan bebas $(\Delta \mathrm{G})$ yang paling rendah. Kompleks ligan-reseptor yang terbentuk divisualisasikan dengan bantuan perangkat lunak Discovery Studio Visualizer v17.2.0.1634.

\section{Simulasi Dinamika Molekul}

Simulasi dinamika molekul dilakukan dengan menggunakan perangkat lunak AMBER 16. AMBER terdiri atas 1) antechamber menghasilkan berkas konversi dan dapat menentukan muatan dan tipe atom; 2) parmchk2 untuk memperoleh parameter medan gaya yang hilang; 3) LEaP digunakan untuk mengonstruksi berkas medan gaya; 4) sander merupakan program utama MD digunakan untuk minimisasi energi dan melakukan simulasi dinamika molekular; 5) cpptraj untuk menghasilkan tipe analisis dan dapat melakukan proses lintasan atom (Case et al., 2014; Salomon-Ferrer et al., 2013; Roe and Cheatham, 2013). Analisis hasil simulasi dinamika molekul dilakukan pada tiga aspek yakni Root Mean Square Deviation (RMSD), Root Mean Square Fluctuation (RMSF), dan perhitungan energi ikatan metode Molecular Mechanics-Generalized Born Surface Area (MM-GBSA) (Dermawan et al., 2019)

\section{HASIL DAN PEMBAHASAN}

\section{Screening Farmakokinetik dan Lipinski Rule of Five}

Hasil analisis GCMS rimpang Bangle (Zingiber purpureum Roxb.) berjumlah 31 senyawa yang kemudian di screening farmakokinetik (Tabel 1) dan Lipinski Rule of Five (Tabel 2). Prediksi aspek farmakokinetika dan toksisitas dilakukan dengan menggunakan program berbasis web yaitu PreADMET. Parameter yang digunakan untuk studi ADME adalah nilai Caco-2, HIA (Human Intestinal Absorption), Plasma Protein Binding. Parameter Caco-2 digunakan untuk menentukan nilai permeabilitas senyawa. HIA (Human Intestinal Absorption) digunakan untuk memprediksikan persen penyerapan obat di usus manusia dan Protein Plasma Binding digunakan untuk mengetahui nilai dalam persen suatu obat yang terikat dengan protein plasma.

Berdasarkan Tabel 1, kontrol positif (ibuprofen, dan 4-hydroxytamoxifen (4-OHT) dan seluruh senyawa pada minyak atsiri rimpang bangle diprediksi memiliki nilai permeabilitas yang sedang yaitu $4-70$. Persentase penyerapan di usus manusia termasuk ke dalam rentang yang baik yaitu $70 \%-100 \%$, dan persentase pengikatan protein darah memiliki nilai yang tinggi yaitu $>90 \%$ yang menunjukkan ikatan yang kuat dengan protein plasma, tetapi senyawa ibuprofen, sabinene; benzene 1-methyl-3-(1-methylethyl); 1,4-naphthalenedione-2-ethyl-3hydroxy; 3H-indole,2,3,3-trimethyl dan phenylmethylene memiliki persentase pengikatan protein darah yang rendah yaitu <90\% masing-masing $88,25 \% ; 0 \% ; 60,97 \% ; 88,39 \% ; 86,71 \% ; 44,57 \%$; dan $79,62 \%$ yang menunjukkan ikatan yang lemah dengan protein plasma dalam artian mampu terdistribusi dengan baik. Hal ini sesuai dengan teori yang menyatakan bahwa obat yang terikat dengan protein plasma bersifat inaktif, hanya obat bebas dan tidak terikat yang dapat bekerja pada target sehingga menghasilkan suatu respons biologis, dan dapat masuk ke dalam proses eliminasi (Harvey et al., 2013). 
Tabel 1. Hasil Prediksi Aspek Farmakokinetika dan Toksisitas.

\begin{tabular}{|c|c|c|c|c|c|c|}
\hline \multirow{2}{*}{$\begin{array}{l}\text { Nama } \\
\text { Senyawa }\end{array}$} & \multicolumn{3}{|c|}{ Prediksi Farmakokinetik } & \multicolumn{3}{|c|}{ Toksisitas } \\
\hline & Caco2 & HIA & PPB & Ames test & Carcino mouse & Carcino rat \\
\hline Ibuprofen & $21,21^{b}$ & $98,38^{\mathrm{c}}$ & $88,25^{b}$ & Mutagen & - & - \\
\hline $4-\mathrm{OHT}$ & $47,74^{\mathrm{b}}$ & $97,20^{\mathrm{c}}$ & $99,51^{\mathrm{a}}$ & Non Mutagen & - & - \\
\hline Alpha Pinene & $23,63^{b}$ & $100,00^{\mathrm{c}}$ & $100,00^{\mathrm{a}}$ & Mutagen & - & + \\
\hline $\begin{array}{l}\text { Alpha } \\
\text { Phellandrene }\end{array}$ & $23,42^{b}$ & $100,00^{\mathrm{c}}$ & $100,00^{\mathrm{a}}$ & Mutagen & + & + \\
\hline Alpha Thujene & $23,63^{b}$ & $100,00^{\mathrm{c}}$ & $100,00^{\mathrm{a}}$ & Mutagen & - & + \\
\hline $\begin{array}{l}\text { 1,3,6-Octatriene, } \\
\text { 3,7-dimethyl- }\end{array}$ & $23,63^{b}$ & $100,00^{c}$ & $100,00^{\mathrm{a}}$ & Mutagen & + & + \\
\hline Sabinene & $23,49^{b}$ & $100,00^{\mathrm{c}}$ & $60,97^{\mathrm{b}}$ & Mutagen & - & + \\
\hline Delta.3-Carene & $23,63^{b}$ & $100,00^{\mathrm{c}}$ & $100,00^{\mathrm{a}}$ & Mutagen & - & + \\
\hline Beta.-Pinene & $23,49^{b}$ & $100,00^{\mathrm{c}}$ & $100,00^{a}$ & Mutagen & - & + \\
\hline Myrcene & $23,63^{b}$ & $100,00^{c}$ & $100,00^{\mathrm{a}}$ & Mutagen & - & + \\
\hline Alpha.-Terpinene & $23,45^{b}$ & $100,00^{\mathrm{c}}$ & $100,00^{\mathrm{a}}$ & Mutagen & + & + \\
\hline Alpha.-terpinolene & $23,64^{\mathrm{b}}$ & $100,00^{\mathrm{c}}$ & $93,16^{\mathrm{a}}$ & Mutagen & + & + \\
\hline Delta-4-Carene & $23,63^{b}$ & $100,00^{c}$ & $100,00^{a}$ & Mutagen & - & + \\
\hline P-Cimene & $23,43^{b}$ & $100,00^{c}$ & $100,00^{\mathrm{a}}$ & Mutagen & + & - \\
\hline $\begin{array}{l}\text { Benzene, } 1- \\
\text { methyl-2-(1- } \\
\text { methylethyl)- }\end{array}$ & $23,43^{b}$ & $100,00^{c}$ & $88,39^{\mathrm{b}}$ & Mutagen & + & - \\
\hline $\begin{array}{l}\text { Benzene, } 1- \\
\text { methyl-3-(1- } \\
\text { methylethyl)- }\end{array}$ & $23,46^{\mathrm{b}}$ & $100,00^{c}$ & $100,00^{\mathrm{a}}$ & Mutagen & - & - \\
\hline Ocimene & $23,49^{b}$ & $100,00^{\mathrm{c}}$ & $100,00^{\mathrm{a}}$ & Mutagen & + & + \\
\hline Gamma-Terpinene & $23,64^{\mathrm{b}}$ & $100,00^{\mathrm{c}}$ & $100,00^{\mathrm{a}}$ & Mutagen & + & + \\
\hline $\begin{array}{l}\text { 3-Octen-5-yne, } \\
\text { 2,7-dimethyl }\end{array}$ & $23,59^{b}$ & $100,00^{\mathrm{c}}$ & $100,00^{\mathrm{a}}$ & Mutagen & + & + \\
\hline Terpineol-4 & $50,81^{\mathrm{b}}$ & $100,00^{c}$ & $100,00^{\mathrm{a}}$ & Mutagen & + & - \\
\hline $\begin{array}{l}\text { Alpha-Terpinyl } \\
\text { acetate }\end{array}$ & $37,76^{b}$ & $100,00^{c}$ & $98,54^{\mathrm{a}}$ & Mutagen & - & - \\
\hline Beta-Farnesene & $23,40^{b}$ & $100,00^{c}$ & $100,00^{\mathrm{a}}$ & Non Mutagen & + & + \\
\hline $\begin{array}{l}\text { Beta-sesqui } \\
\text { phellandrene }\end{array}$ & $23,40^{\mathrm{b}}$ & $100,00^{\mathrm{c}}$ & $100,00^{\mathrm{a}}$ & Mutagen & + & + \\
\hline $\begin{array}{l}\text { Geraniol } \\
\text { Trans-3- }\end{array}$ & $8,75^{b}$ & $100,00^{\mathrm{c}}$ & $100,00^{\mathrm{a}}$ & Mutagen & + & - \\
\hline $\begin{array}{l}\text { Undecene-1,5- } \\
\text { diyne }\end{array}$ & $24,03^{\mathrm{b}}$ & $100,00^{c}$ & $100,00^{\mathrm{a}}$ & Mutagen & + & + \\
\hline $\begin{array}{l}\text { 3,5-Dodecadiyne, } \\
\text { 2-methyl }\end{array}$ & $22,54^{b}$ & $100,00^{c}$ & $100,00^{\mathrm{a}}$ & Mutagen & + & + \\
\hline Myristicin & $57,43^{b}$ & $100,00^{c}$ & $96,98^{\mathrm{a}}$ & Mutagen & + & + \\
\hline $\begin{array}{l}\text { Cis-3-Undecene- } \\
\text { 1,5-diyne } \\
\text { 1,4-Naphtha }\end{array}$ & $24,03^{b}$ & $100,00^{c}$ & $100,00^{\mathrm{a}}$ & Mutagen & + & + \\
\hline $\begin{array}{l}\text { lenedione, 2-ethyl- } \\
\text { 3-hydroxy- }\end{array}$ & $20,14^{\mathrm{b}}$ & $94,85^{\mathrm{c}}$ & $86,71^{\mathrm{b}}$ & Mutagen & + & + \\
\hline Naphthalene & $23,41^{b}$ & $100,00^{\mathrm{c}}$ & $100,00^{\mathrm{a}}$ & Mutagen & + & + \\
\hline $\begin{array}{l}\text { 3H-Indole, } 2,3,3- \\
\text { trimethyl- }\end{array}$ & $35,94^{\mathrm{b}}$ & $100,00^{c}$ & $44,57^{b}$ & Mutagen & - & + \\
\hline Biphenylene & $23,40^{\mathrm{b}}$ & $100,00^{\mathrm{c}}$ & $100,00^{\mathrm{a}}$ & Mutagen & + & + \\
\hline Phenylmethylene & $20,74^{\mathrm{b}}$ & $88,16^{\mathrm{c}}$ & $79,62^{b}$ & Mutagen & - & + \\
\hline
\end{tabular}

Keterangan: Caco-2 (<4 Rendah ${ }^{\mathrm{a}} ; 4-70$ Sedang $^{\mathrm{b}} ;>70$ Tinggi $^{\mathrm{c}}$

HIA ( $0 \%-20 \%$ Buruk $^{\mathrm{a}} ; 20 \%-70 \%$ Sedang ${ }^{\mathrm{b}} ; 70-100 \%$ Baik $\left.^{\mathrm{c}}\right)$

PPB ( $>90 \%$ Terikat Kuat ${ }^{\text {a }} ;<90 \%$ Terikat Lemah ${ }^{\text {b) }}$ 


\section{Screening Ligand Based Drug Likeness (Drugs Scan)}

Senyawa terpilih hasil screening farmakokinetik sabinene; benzene 1-methyl-3-(1-methylethyl); 1,4naphthalenedione-2-ethyl-3-hydroxy; 3H-indole-2,3,3-trimethyl dan phenylmethylene dilanjutkan dengan screening prediksi Lipinski Rule of Five. Drug likeness mengacu pada pemberian obat secara oral yang berhubungan dengan proses absorpsi dan distribusi obat. Kriteria obat yang baik harus mengikuti sebuah aturan Lipinski's Rule of Five. Aturan yang ditetapkan oleh Lipinski's Rule of Five yaitu berat molekul $<500 \mathrm{~g} / \mathrm{mol}, \mathrm{log}$ $\mathrm{P}<5$, donor ikatan hidrogen $<5$, akseptor ikatan hidrogen $<10$, dan refractory molar antara $40-130$. Data penerapan aturan Lipinski dapat dilihat pada Tabel 2.

Tabel 2. Hasil uji drug scan menurut aturan Lipinski's Rule of Five.

\begin{tabular}{lccccc}
\hline \multirow{2}{*}{\begin{tabular}{l} 
Sama \\
\cline { 2 - 6 }
\end{tabular}} & $\begin{array}{c}\text { Berat } \\
\text { molekul }\end{array}$ & $\begin{array}{c}\text { Donor } \\
\text { proton }\end{array}$ & $\begin{array}{c}\text { Akseptor } \\
\text { proton }\end{array}$ & Log P & Refractory Molar \\
\cline { 2 - 6 } & $\mathbf{5 0 0} \mathbf{~ g / m o l}$ & $<\mathbf{5}$ & $<\mathbf{1 0}$ & $<\mathbf{5}$ & $\mathbf{4 0 - 1 3 0}$ \\
\hline $\begin{array}{l}\text { Ibuprofen } \\
\text { 4-OHT }\end{array}$ & 206,13 & 1 & 3 & 3,75 & 60,73 \\
Sabinene & 387,22 & 1 & 3 & 5,68 & 130,41 \\
Benzene, 1-methyl-3-(1- & 136,13 & 0 & 0 & 2,95 & 43,65 \\
methylethyl)- & 134,11 & 0 & 0 & 3,76 & 45,29 \\
$\begin{array}{l}\text { 1,4-Naphthalenedione- 2-ethyl-3- } \\
\text { hydroxy- }\end{array}$ & 202,06 & 1 & 5 & 0,52 & 57,11 \\
3H-Indole- 2,3,3-trimethyl- & 159,1 & 0 & 1 & 2,74 & 52,68 \\
Phenylmethylene & 192,04 & 2 & 6 & 1,35 & 49,13 \\
\hline
\end{tabular}

Berdasarkan Tabel 2 dapat dinyatakan bahwa senyawa ibuprofen, sabinene; benzene 1-methyl-3-(1methylethyl); 1,4-naphthalenedione-2-ethyl-3-hydroxy; 3H-indole-2,3,3-trimethyl dan phenylmethylene memenuhi kriteria aturan Lipinski's Rule of Five sehingga berpotensi dapat diadministrasikan secara oral, tetapi senyawa 4-hidroxytamoxifen (4-OHT) tidak memenuhi kriteria aturan Lipinski's Rule of Five pada parameter log $\mathrm{P}(5,68)$ dan refractory molar $(130,41)$.

Nilai berat molekul berhubungan dengan proses distribusi obat yang terjadi dengan cara menembus membran biologis melalui proses difusi. Senyawa dengan berat molekul $>500 \mathrm{~g} / \mathrm{mol}$ akan sulit untuk menembus membran biologis sehingga waktu absorpsi obat akan membutuhkan waktu yang lama. Beda halnya dengan senyawa yang memiliki berat molekul lebih kecil akan lebih mudah menembus membran biologi (Adriani, 2018).

Nilai $\log \mathrm{P}$ berhubungan dengan hidrofobisitas atau lipofilisitas suatu senyawa. Semakin besar nilai log P maka senyawa akan bersifat hidrofobik. Jika nilai $\log \mathrm{P}>5$ menyebabkan suatu senyawa akan lebih lama tinggal di lipid bilayer dan terdistribusi lebih luas di dalam tubuh. Hal ini menyebabkan selektivitas ikatan terhadap enzim target menjadi berkurang dan cenderung memiliki toksisitas yang lebih tinggi. Nilai log P senyawa tidak boleh negatif karena tidak dapat melewati membran lipid bilayer dan memungkinkan terjadi interaksi dengan pelarut air (Kilo et al., 2019).

Jumlah ikatan hidrogen pada donor dan akseptor berkolerasi dengan aktivitas biologis suatu senyawa. Semakin tinggi kapasitas ikatan pada donor dan akseptor, maka semakin tinggi energi yang dibutuhkan agar proses absorpsi dapat terjadi (Syahputra et al., 2014). Refractory molar adalah suatu nilai total polarisabilitas dari suatu molekul obat (Ruswanto, 2020), dimana suatu senyawa non polar dapat membentuk momentum agar senyawa dapat berikatan dengan reseptor dan sifat polar berfungsi agar sisa dari metabolisme senyawa dapat diekskresikan dari tubuh.

\section{Docking Senyawa dan Visualisasi Interaksi terhadap Protein Target}

Ibuprofen dan tamoxifen merupakan senyawa obat antiinflamasi dan antikanker payudara yang ada di pasaran. Pemilihan ibuprofen sebagai senyawa pembanding yaitu berdasarkan mekanisme kerjanya yang menghambat pembentukan prostaglandin dari asam arakidonat melalui penghambatan enzim cyclooxygenase, sedangkan pemilihan tamoxifen sebagai senyawa pembanding antikanker payudara yaitu berdasarkan mekanisme kerjanya yang dapat menghalangi ikatan estrogen terhadap ER $\alpha$ sehingga dapat mencegah pertumbuhan sel tumor dan angiogenesis. Reseptor yang dipilih untuk simulasi penambatan molekul yaitu cyclooxygenase-1 (COX-1) 
dengan kode ID PDB 1EQG (antiinflamasi) serta ER $\alpha$ dengan kode ID PDB 3ERT (antikanker payudara). Hasil validasi docking ditampilkan pada Tabel 3.

Tabel 3. Hasil validasi Metode Docking.

\begin{tabular}{lccccc}
\hline \multirow{2}{*}{ Kode PDB } & \multicolumn{3}{c}{ Grid Box } & \multirow{2}{*}{ RMSD $(\AA) \leq 2$} & \multirow{2}{*}{ Binding affinity (kkal/mol) } \\
\cline { 2 - 4 } 1EQG (IBP) & 26,643 & 33,106 & 200,231 & 0,95 & $-8,38$ \\
3ERT (4-OHT) & 30,191 & $-1,913$ & 24,207 & 1,17 & $-11,23$ \\
\hline
\end{tabular}

Reseptor 1EQG (IBP) dan 3ERT (4-OHT) dilakukan proses validasi reseptor (redocking) terlebih dahulu untuk membuktikan dan memastikan bahwa metode yang akan digunakan telah memenuhi syarat validitas dan dapat digunakan untuk pengujian senyawa lainnya serta dapat meminimalisir kesalahan. Metode docking dikatakan baik jika memiliki nilai Root Mean Square Deviation (RMSD) yang dihasilkan $\leq 2 \AA$. Hasil validasi metode docking dapat dilihat pada Tabel 3 dan Gambar 1.
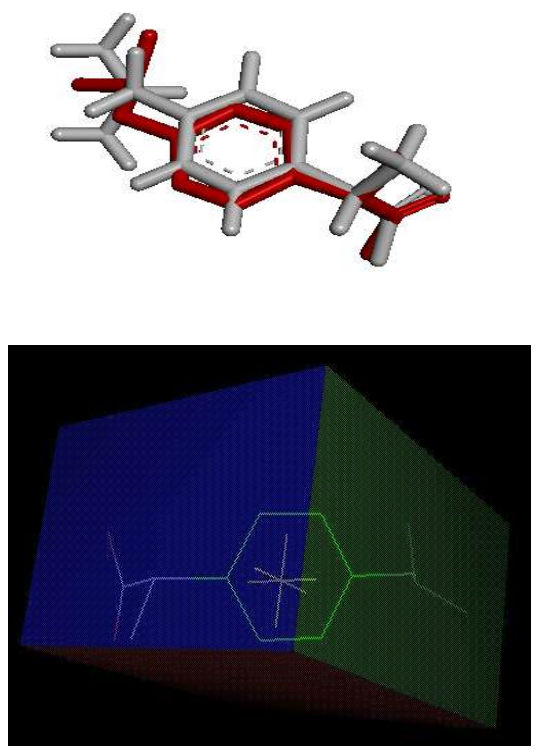

(a)
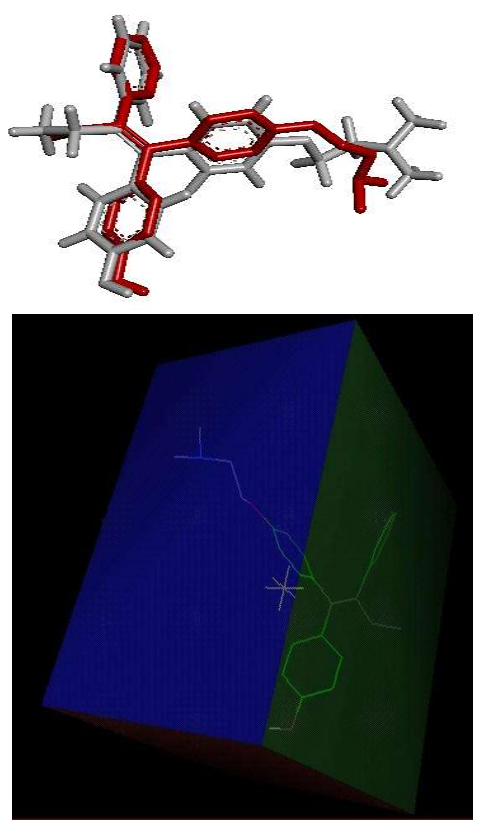

(b)

Gambar 1. (a) Overlay Konformasi IBP (merah) hasil validasi dengan IBP hasil kristalografi (putih) (1EQG) dan (b) 4-OHT (merah) hasil validasi dengan 4-OHT hasil kristalografi (putih) (3ERT).

Hasil penambatan molekul Ibuprofen serta senyawa hasil GC-MS minyak atsiri rimpang bangle terhadap COX-1 pada Tabel 4.

Tabel 4. Hasil Penambatan Ibuprofen serta Senyawa terlipih terhadap COX-1.

\begin{tabular}{|c|c|c|c|c|}
\hline \multirow[b]{2}{*}{ Nama Senyawa } & \multirow[b]{2}{*}{$\begin{array}{c}\Delta G \\
\text { kkal/mol }\end{array}$} & \multirow[b]{2}{*}{$\begin{array}{c}\mathbf{K i} \\
(\mu \mathbf{M})\end{array}$} & \multicolumn{2}{|c|}{ Interaksi dengan Asam Amino } \\
\hline & & & $\begin{array}{l}\text { Ikatan } \\
\text { Hidrogen }\end{array}$ & $\begin{array}{c}\text { Ikatan } \\
\text { Hidrofobik }\end{array}$ \\
\hline Ibuprofen & $-8,38$ & 0,71 & $\begin{array}{l}\text { Tyr355, } \\
\text { Arg120 }\end{array}$ & $\begin{array}{c}\text { Ser530, Ser353, Gly526, Phe381, } \\
\text { Leu352 }\end{array}$ \\
\hline Sabinene & $-5,81$ & 55,01 & & Gly526, Ser530 \\
\hline Benzene, 1-methyl-3-(1-methylethyl)- & $-5,51$ & 92,00 & & Ser530 \\
\hline $\begin{array}{l}\text { 1,4-naphthalenedione-2-ethyl-3- } \\
\text { hydroxy }\end{array}$ & $-7,20$ & 5,26 & $\begin{array}{l}\text { Ser530, } \\
\text { Tyr385 }\end{array}$ & $\begin{array}{c}\text { Ser353, Phe518, Met522, Trp387, } \\
\text { Gly526, Tyr348 }\end{array}$ \\
\hline 3H-Indole, 2,3,3-trimethyl- & $-6,37$ & 21,51 & & $\begin{array}{c}\text { Phe381, Ser530, Ser353, Gly526, } \\
\text { Leu384, Ile523, Phe518 }\end{array}$ \\
\hline Phenylmethylene & $-6,94$ & 8,20 & $\begin{array}{l}\text { Tyr355, } \\
\text { Arg120 }\end{array}$ & $\begin{array}{c}\text { Phe518, Ser353, Val116, Leu359, } \\
\text { Leu351 }\end{array}$ \\
\hline
\end{tabular}


Berdasarkan hasil simulasi penambatan molekul yang ditunjukkan oleh Tabel 4, dapat diketahui afinitas ikatan antara ligan dengan reseptornya. Seluruh senyawa hasil GC-MS minyak atsiri rimpang bangle memiliki nilai energi bebas $(\Delta G)$ yang lebih besar dibandingkan dengan senyawa pembanding antiinflamasi yang ada dipasaran yaitu ibuprofen. Nilai energi bebas $(\Delta \mathrm{G})$ senyawa hasil GC-MS minyak atsiri rimpang bangle yang paling kecil adalah senyawa 1,4-naphthalenedione-2-ethyl-3-hydroxy dengan nilai $\Delta \mathrm{G}-7,20 \mathrm{kkal} / \mathrm{mol}$ dan nilai $\mathrm{Ki}$ $5,26 \mu \mathrm{M}$. Nilai energi bebas $(\Delta \mathrm{G})$ senyawa ibuprofen adalah $-8,38 \mathrm{kkal} / \mathrm{mol}$ dengan nilai $\mathrm{Ki} 0,71 \mu \mathrm{M}$, sehingga tingkat afinitas ibuprofen terhadap COX-1 lebih tinggi dibandingkan dengan senyawa 1,4-naphthalenedione-2ethyl-3-hydroxy. Hal ini menunjukkan bahwa ibuprofen diprediksi mempunyai interaksi yang stabil dan paling baik terhadap COX-1, yang mengindikasikan bahwa ibuprofen lebih poten sebagai obat antiinflamasi dari pada senyawa 1,4-naphthalenedione-2-ethyl-3-hydroxy.

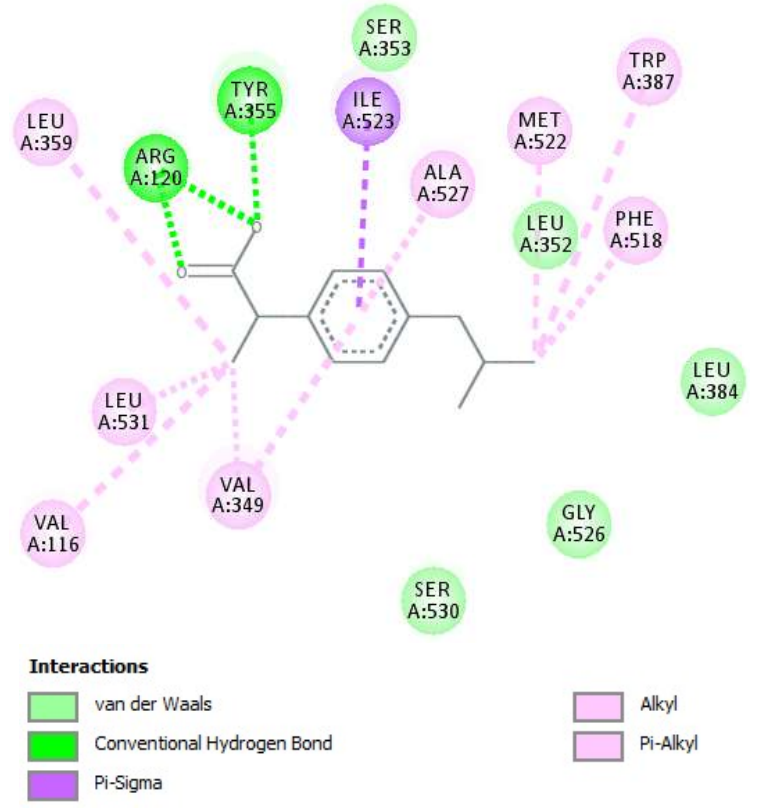

(a)

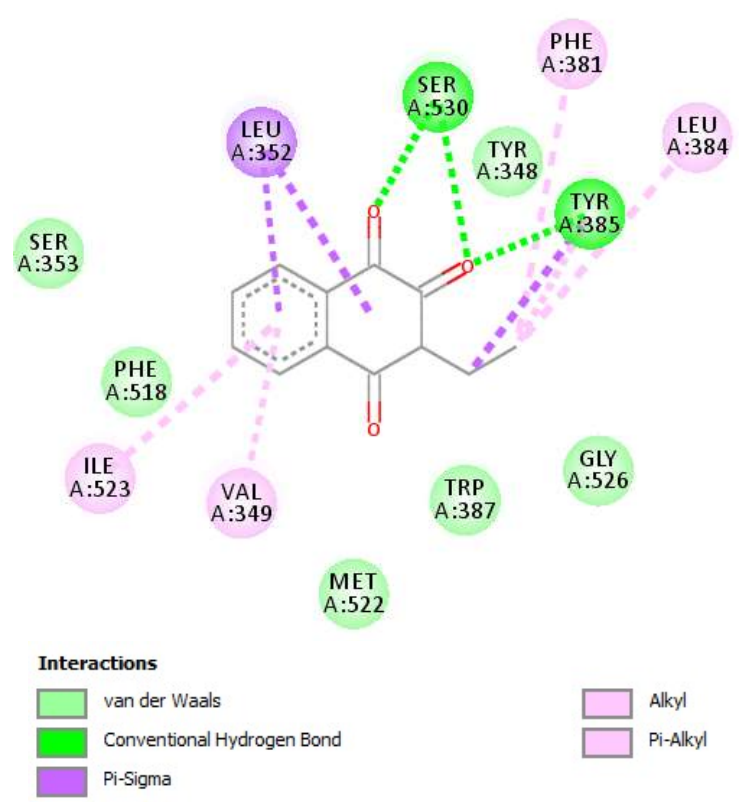

(b)

Gambar 2. (a) Visualisasi 2D penambatan molekul Ibuprofen dan (b) 1,4-naphthalenedione-2-ethyl-3-hydroxy.

Gambar 2 menunjukkan adanya kesamaan ikatan hidrofobik yang terjadi pada senyawa terpilih 1,4naphthalenedione-2-ethyl-3-hydroxy dan ibuprofen yakni Ser353 dan. Gly526. Adanya kesamaan ikatan hidrofobik ini menandakan tingkat kelarutan obat dalam membran sel dan diprediksi bisa terikat baik pada sisi reseptor seperti halnya obat ibuprofen.

Hasil penambatan molekul 4-hydroxytamoxifen (4-OHT) serta senyawa hasil GC-MS minyak atsiri rimpang bangle terhadap ER $\alpha$ pada Tabel 5.

Tabel 5. Hasil penambatan 4-OHT serta senyawa terlipih terhadap ER $\alpha$.

\begin{tabular}{|c|c|c|c|c|}
\hline \multirow[b]{2}{*}{ Nama Senyawa } & \multirow[b]{2}{*}{$\begin{array}{c}\Delta \mathbf{G} \\
\mathrm{kkal} / \mathrm{mol}\end{array}$} & \multirow[b]{2}{*}{$\begin{array}{c}\mathbf{K i} \\
(\mu \mathbf{M})\end{array}$} & \multicolumn{2}{|c|}{ Interaksi dengan Asam Amino } \\
\hline & & & $\begin{array}{c}\text { Ikatan } \\
\text { Hidrogen }\end{array}$ & $\begin{array}{c}\text { Ikatan } \\
\text { Hidrofobik }\end{array}$ \\
\hline 4-OHT & $-11,23$ & 0,005 & $\begin{array}{l}\text { Arg394, } \\
\text { Glu353 }\end{array}$ & $\begin{array}{c}\text { Leu349, Gly521, His524, Gly420, } \\
\text { Glu419, Met343, Ile424, Leu346, } \\
\text { Phe404, Leu354, Leu384 }\end{array}$ \\
\hline Sabinene & $-5,00$ & 215,77 & & Arg394, Glu353 \\
\hline $\begin{array}{l}\text { Benzene, 1-methyl-3-(1- } \\
\text { methylethyl })-\end{array}$ & $-4,79$ & 306,80 & & $\begin{array}{c}\text { Leu384, Ile424, Leu387, Glu353, } \\
\text { Arg394 }\end{array}$ \\
\hline $\begin{array}{l}\text { 1,4-naphthalenedione-2-ethyl-3- } \\
\text { hydroxy }\end{array}$ & $-6,00$ & 40,30 & Arg394 & $\begin{array}{c}\text { Met421, Ile424, Leu428, Leu387, } \\
\text { Glu353 }\end{array}$ \\
\hline 3H-Indole, 2,3,3-trimethyl- & $-5,75$ & 61,28 & & Leu428, Leu384, Glu353, Arg394 \\
\hline Phenylmethylene & $-3,91$ & 1350 & & $\begin{array}{c}\text { Glu353, Phe404, Leu391, Leu384, } \\
\text { Thr347, Leu525, Trp383 }\end{array}$ \\
\hline
\end{tabular}


Berdasarkan Tabel 5, dapat diketahui afinitas ikatan antara ligan dengan reseptornya. Seluruh senyawa hasil GC-MS minyak atsiri rimpang bangle memiliki nilai energi bebas $(\Delta \mathrm{G})$ yang lebih besar dibandingkan dengan senyawa pembanding antikanker payudara yang ada dipasaran yaitu 4-hydroxytamoxifen (4-OHT). Nilai energi bebas $(\Delta \mathrm{G})$ senyawa hasil GC-MS minyak atsiri rimpang bangle yang paling kecil adalah senyawa 1,4naphthalenedione-2-ethyl-3-hydroxy dengan nilai $\Delta \mathrm{G}$ sebesar $-6,00 \mathrm{kkal} / \mathrm{mol}$ dan nilai $\mathrm{Ki} 40.30 \mu \mathrm{M}$. Nilai energi bebas $(\Delta \mathrm{G})$ senyawa 4-hydroxytamoxifen (4-OHT) adalah $-11,23 \mathrm{kkal} / \mathrm{mol}$ dengan nilai Ki $0.005 \mu \mathrm{M}$, sehingga tingkat afinitas 4-hydroxytamoxifen (4-OHT) terhadap ER $\alpha$ lebih tinggi dibandingkan dengan senyawa 1,4naphthalenedione-2-ethyl-3-hydroxy. Hal ini menunjukkan bahwa senyawa 4-hydroxytamoxifen (4-OHT) diprediksi mempunyai interaksi yang stabil dan lebih poten sebagai obat antikanker payudara dari pada senyawa 1,4-naphthalenedione-2-ethyl-3-hydroxy.

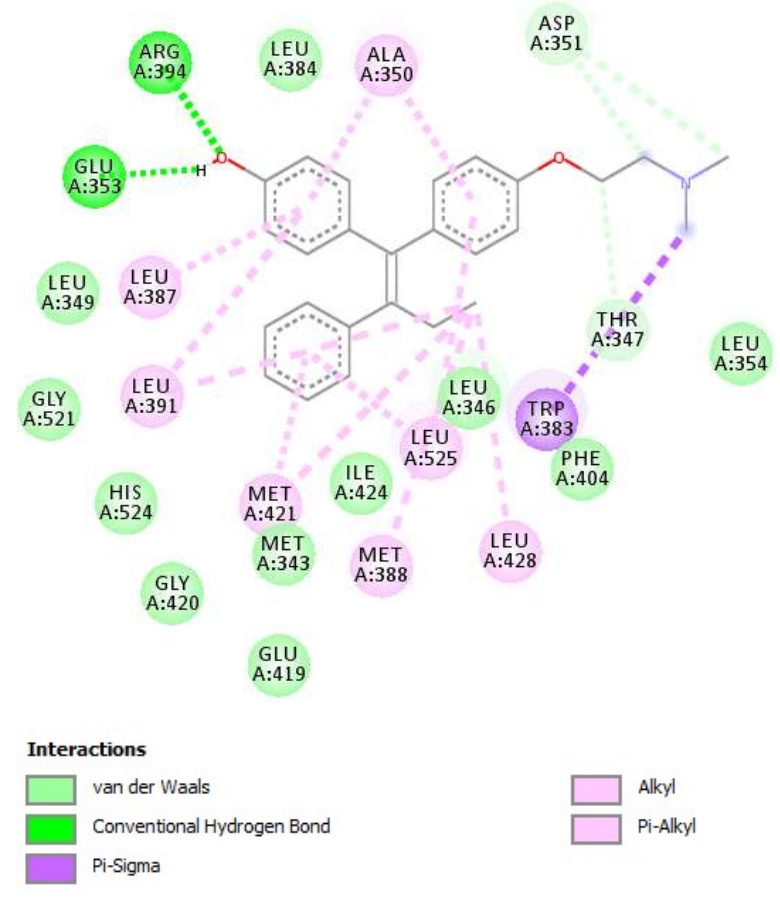

(a)

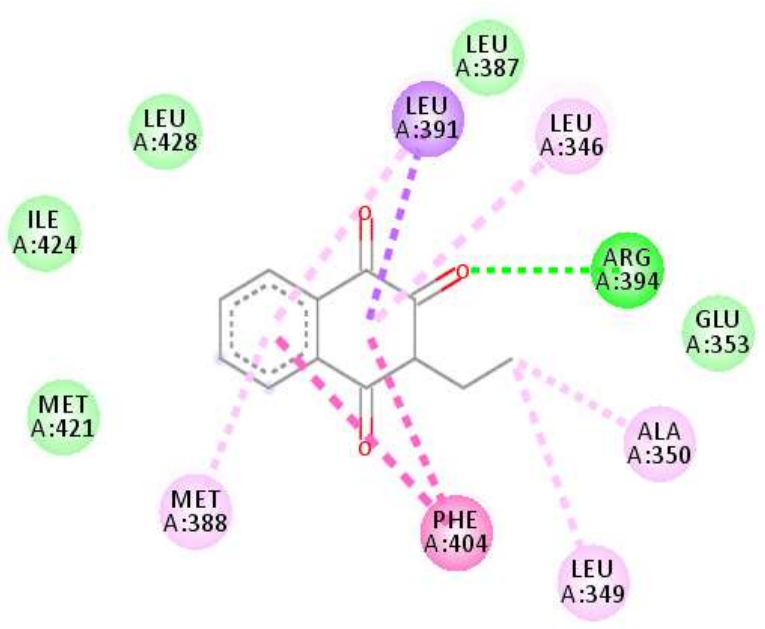

Interactions

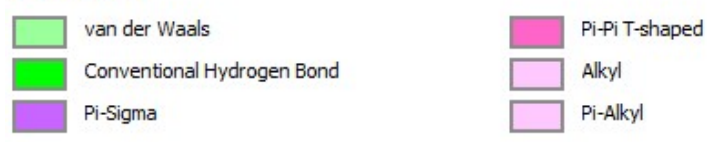

(b)

Gambar 3. (a) Visualisasi 2D penambatan molekul 4-OHT dan (b) 1,4-naphthalenedione-2-ethyl-3-hydroxy.

Interaksi ligan pada kantung aktif reseptor perlu untuk diidentifikasi agar dapat menentukan ikatan yang terjadi antara ligan dengan residu asam amino dari reseptor ER $\alpha$. Semakin banyak interaksi ikatan hidrogen antara senyawa dengan residu asam amino maka diprediksi interaksinya akan semakin stabil dan baik. Ikatan yang perlu diperhatikan adalah ikatan hidrogen antara ligan dengan residu asam amino His524 dikarenakan dapat menentukan suatu ligan bersifat agonis atau antagonis. ER $\alpha$ memiliki Ligand Binding Domain (LBD) atau sisi pengikatan ligan yang didominasi oleh daerah hidrofobik yang menyusun helix 3, 6, 7, 8, 11, dan 12. Senyawa bersifat agonis apabila memiliki interaksi ikatan hidrogen dengan His524 yang menyebabkan helix-12 terbuka dan berikatan dengan koaktivator sehingga senyawa bersifat agonis begitu pula sebaliknya. Senyawa akan bersifat antagonis ketika tidak memiliki interaksi ikatan hidrogen dengan His524 (Muchtaridi et al., 2014). Hasil penelitian menunjukkan bahwa 4-hydroxytamoxifen (4-OHT) dan 1,4-naphthalenedione-2-ethyl-3-hydroxy diprediksi bersifat antagonis dikarenakan tidak membentuk interaksi ikatan hidrogen dengan His524.

\section{Simulasi Dinamika Molekular}

Interaksi yang terjadi pada penambatan molekul kemudian diuji secara dinamika molekular dengan waktu 10 ns (10000 ps) diperoleh nilai Root Mean Square Deviation (RMSD) dan Root Mean Square Fluctuation (RMSF). RMSD digunakan untuk membandingkan pergeseran atau perubahan konformasi molekul selama proses simulasi 
berlangsung. RMSD senyawa Ibuprofen dan 1,4-naphthalenedione-2-ethyl-3-hydroxy terhadap COX-1 ditunjukkan pada Gambar 4.

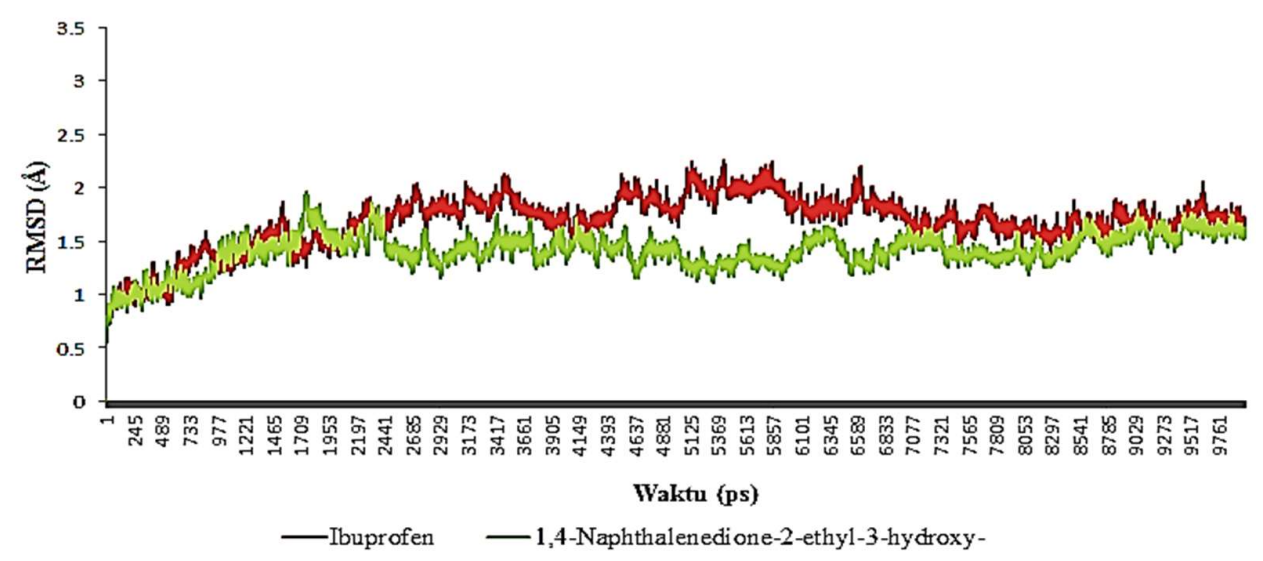

Gambar 4. Nilai RMSD sistem ibuprofen dan 1,4-naphthalenedione-2-ethyl-3-hydroxy terhadap COX-1.

Berdasarkan Gambar 4, waktu yang dibutuhkan kompleks ibuprofen dan 1,4-naphthalenedione-2-ethyl-3hydroxy terhadap COX-1 untuk mencapai konformasi yang stabil adalah relatif sama, dimana sistem mencapai kondisi stabil secara umum setelah simulasi berjalan pada waktu 7000 ps (7 ns) hingga simulasi berakhir. RMSD tertinggi dicapai oleh ibuprofen yakni sebesar $\pm 1,9 \AA$, dan nilai terendah dicapai oleh 1,4-naphthalenedione-2ethyl-3-hydroxy dengan nilai RMSD sebesar $\pm 1,5 \AA$. Hal ini menunjukkan bahwa 1,4-naphthalenedione-2-ethyl3-hydroxy diprediksi memiliki interaksi yang lebih stabil terhadap COX-1 daripada ibuprofen.

RMSD senyawa 4-OHT dan 1,4-naphthalenedione-2-ethyl-3-hydroxy terhadap ER $\alpha$ ditunjukkan pada Gambar 5.

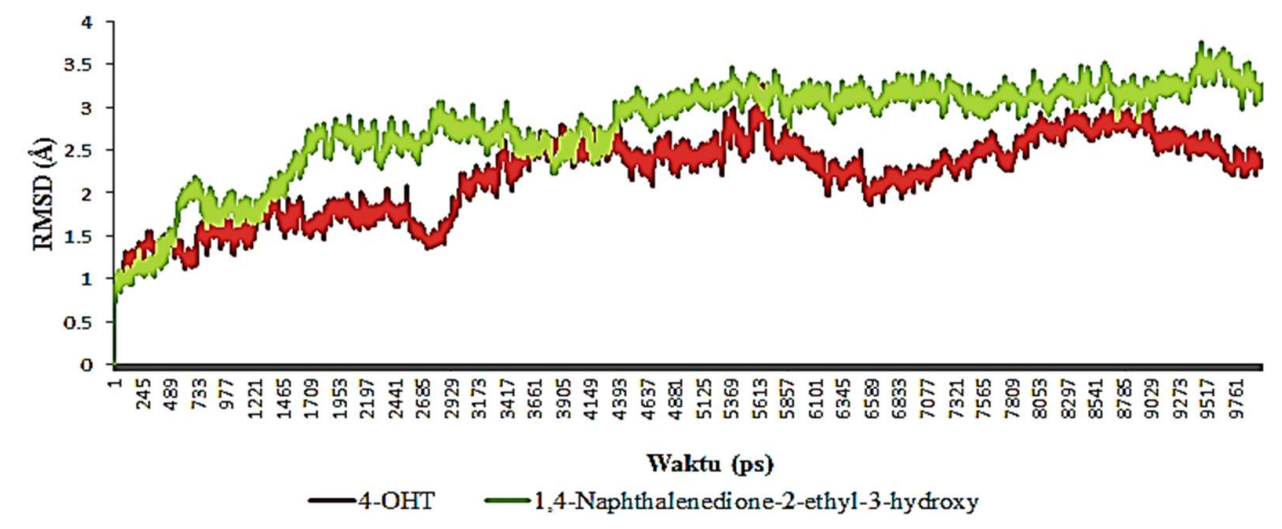

Gambar 5. Nilai RMSD Sistem 4-OHT dan 1,4-naphthalenedione-2-ethyl-3-hydroxy terhadap ER $\alpha$.

Berdasarkan Gambar 5, waktu yang dibutuhkan kompleks 1,4-naphthalenedione-2-ethyl-3-hydroxy terhadap ER $\alpha$ untuk mencapai konformasi yang stabil adalah pada waktu 4000 ps (4 ns), sedangkan 4-OHT belum mencapai konformasi yang stabil hingga simulasi berakhir, sehingga diperlukan perpanjangan waktu analisis dalam simulasi dinamika molekuler. RMSD tertinggi dicapai oleh 1,4-naphthalenedione-2-ethyl-3-hydroxy yakni sebesar $\pm 3,3 \AA$, sedangkan 4-OHT memiliki nilai RMSD yakni sebesar $\pm 2,7 \AA$. Hal ini menunjukkan bahwa ER $\alpha$ memiliki fleksibilitas yang lebih tinggi ketika berinteraksi dengan 4-OHT sehingga struktur protein ER $\alpha$ dapat terbuka dan bersifat antagonis terhadap ER $\alpha$.

Berbeda dengan halnya RMSD, nilai RMSF secara garis besar akan menggambarkan fleksibilitas residu asam amino. Residu dengan fluktuasi yang rendah menunjukkan bahwa residu tersebut tidak memberikan fleksibilitas yang tinggi dan dapat dikatakan memiliki interaksi atau ikatan yang stabil dan berperan aktif pada situs pengikatan ligan- reseptor, sedangkan residu dengan fluktuasi tinggi menunjukkan residu tersebut memiliki fleksibilitas yang tinggi dan dapat dikatakan memiliki interaksi atau ikatan yang tidak stabil karena mengalami banyak perubahan posisi saat proses simulasi berlangsung, sehingga dapat dikatakan bahwa residu tersebut tidak berperan aktif pada 
situs pengikatan ligan- reseptor. RMSF sistem ibuprofen dan 1,4-naphthalenedione-2-ethyl-3-hydroxy terhadap COX-1 ditunjukkan pada Gambar 6.

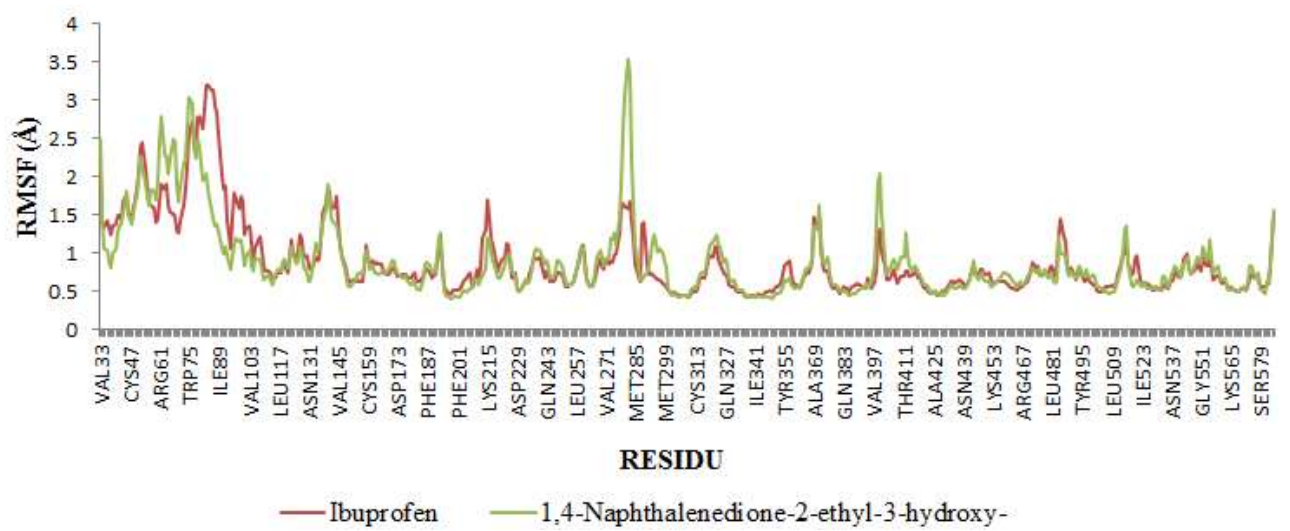

Gambar 6. Nilai RMSF sistem ibuprofen dan 1,4-naphthalenedione-2-ethyl-3-hydroxy terhadap COX-1.

Berdasarkan Gambar 6, residu yang mengalami fluktuasi paling tinggi pada interaksi COX-1 dengan ibuprofen adalah Asp53, Arg83, Glu140, Lys215, dan Ile279, sedangkan pada interaksi COX-1 dengan 1,4Naphthalenedione-2-ethyl-3-hydroxy residu yang mengalami fluktuasi paling tinggi adalah Thr62, Trp75 dan Pro281, sehingga dapat dikatakan bahwa residu tersebut tidak berperan aktif pada situs pengikatan.

Residu yang memiliki fluktuasi rendah pada situs pengikatan interaksi COX-1 dengan ibuprofen adalah Ile337, Ile341 dan Asn310, sedangkan pada interaksi COX-1 dengan 1,4-Naphthalenedione-2-ethyl-3-hydroxy adalah Val349, Phe198 dan Ala199. Berdasarkan data RMSF, residu-residu tersebut memiliki fleksibilitas yang rendah pada masing-masing sistem, sehingga diprediksi bahwa ibuprofen dan 1,4-Naphthalenedione-2-ethyl-3hydroxy berinteraksi dengan stabil pada situs aktif tersebut. RMSF senyawa 4-hydroxytamoxifen (4-OHT) dan 1,4Naphthalenedione- 2-ethyl-3-hydroxy terhadap ER $\alpha$ ditunjukkan pada Gambar 7.

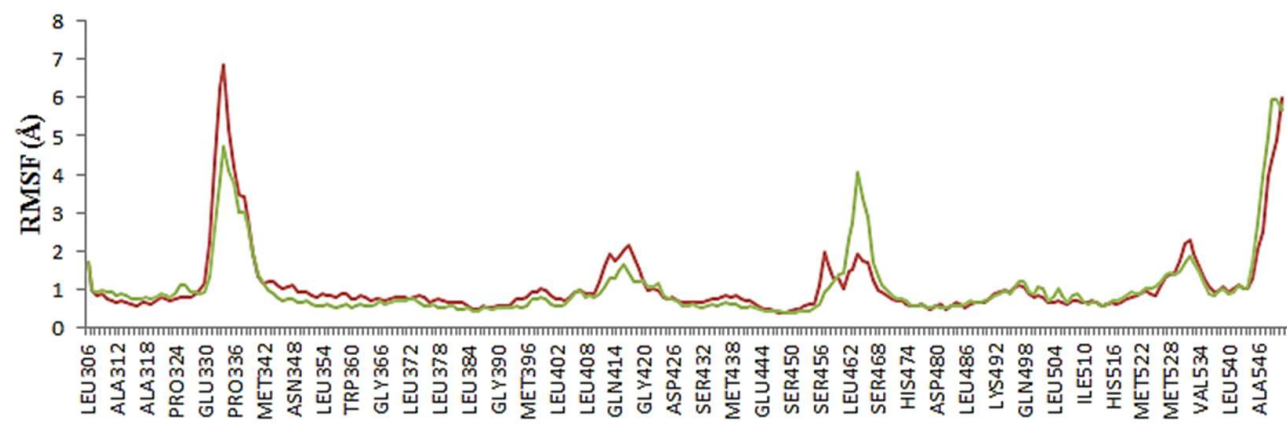

RESIDU

-4-OHT -1,4-Naphthalenedione-2-ethyl-3-hydroxy-

Gambar 7. Nilai RMSF Sistem 4-OHT dan 1,4-naphthalenedione-2-ethyl-3-hydroxy terhadap ER $\alpha$.

Pada Gambar 7, residu yang mengalami fluktuasi paling tinggi pada interaksi ER $\alpha$ dengan senyawa 4-OHT adalah Thr334, Lys416, Gly457, dan Lys531, sedangkan senyawa 1,4-naphthalenedione-2-ethyl-3-hydroxy mengalami fluktuasi yang tinggi pada residu Thr334, Lys416, Ser464 dan Lys531. Struktur protein ER $\alpha$ diketahui memiliki ikatan hidrogen pada residu asam amino yang terbentuk antara Glu419 dengan His524 dan Glu419 dengan Lys531. Jika terjadi fluktuasi yang meningkat pada residu tersebut maka dapat diinterpretasikan bahwa ligan memiliki potensi sebagai antagonis terhadap ER $\alpha$ (Muchtaridi et al., 2014). Senyawa 4-OHT dan 1,4naphthalenedione-2-ethyl-3-hydroxy menggangu ikatan hidrogen tersebut dengan adanya fluktuasi yang meningkat pada residu Lys531 sehingga dapat dikatakan bahwa 4-OHT dan 1,4-naphthalenedione-2-ethyl-3hydroxy memiliki aktivitas sebagai antagonis terhadap ER $\alpha$. 
Hasil analisis RMSD dan RMSF dilanjutkan dengan mengkalkulasi energi kompleks menggunakan hitungan Molecular Mechanics-Generalized Born Surface Area (MM-GBSA). Metode kalkulasi MM-GBSA menghasilkan energi bebas $(\Delta \mathrm{G})$ ikatan sistem ligan-reseptor pada simulasi dinamika molekul. Semakin kecil nilai energi bebas $(\Delta \mathrm{G})$, maka semakin besar kemampuan suatu senyawa untuk berikatan dengan reseptor.

Tabel 6. Kalkulasi energi ikatan sistem ibuprofen dan 1,4-naphthalenedione-2-ethyl-3-hydroxy terhadap COX-1 Metode MM-GBSA.

\begin{tabular}{lcc}
\hline & \multicolumn{2}{c}{ Sistem } \\
\cline { 2 - 3 } Komponen Energi (kkal/mol) & IBP - & $\begin{array}{c}\text { 1,4-Naphthalenedione- } \\
\text { 2-ethyl-3-hydroxy - COX-1 }\end{array}$ \\
\hline Interaksi Van der Waals (VdW) & $-35,62$ & $-23,37$ \\
Energi Elektrostatik (EEL) & $-42,89$ & $-131,91$ \\
Kontribusi Elektrostatik terhadap Energi Bebas Solvasi (EGB) & 48,53 & 134,60 \\
Kontribusi Non-polar terhadap Energi Bebas Solvasi (ESURF) & $-4,71$ & $-3,53$ \\
$\Delta \mathrm{G}_{\text {gas }}$ (VdW + EEL) & $-78,51$ & $-155,29$ \\
$\Delta \mathrm{G}_{\text {solv }}$ (EGB + ESURF) & 43,82 & 131,06 \\
$\Delta \mathrm{G}_{\text {TOTAL }}$ (VdW + EEL + EGB + ESURF) & $-34,68$ & $-24,22$ \\
\hline
\end{tabular}

Berdasarkan Tabel 6, menunjukkan bahwa kompleks ibuprofen - COX-1 memiliki nilai energi bebas ikatan total $\left(\Delta \mathrm{G}_{\text {TOTAL }}\right)$ yang lebih rendah dibandingkan dengan sistem 1,4-naphthalenedione-2-ethyl-3-hydroxy-COX1, dimana energi elektrostatik (EEL) merupakan komponen energi yang paling besar memberikan pengaruhnya terhadap sistem. Nilai total energi bebas ikatan $(\Delta \mathrm{G})$ pada sistem ibuprofen-COX-1 lebih rendah $(-34,68 \mathrm{kkal} / \mathrm{mol})$ dibandingkan dengan 1,4-naphthalenedione-2-ethyl-3-hydroxy (-24,22 kkal/mol). Hal ini menunjukkan bahwa tingkat afinitas Ibuprofen terhadap COX-1 diprediksi lebih baik dan lebih poten sebagai obat antiinflamasi dibandingkan 1,4-naphthalenedione-2-ethyl-3-hydroxy.

Tabel 7. Kalkulasi Energi Ikatan Sistem 4-hydroxytamoxifen (4-OHT) dan 1,4-naphthalenedione-2-ethyl-3hydroxy terhadap ER $\alpha$ metode MM-GBSA.

\begin{tabular}{lcc}
\hline \multirow{2}{*}{ Komponen Energi (kkal/mol) } & \multicolumn{2}{c}{ Sistem } \\
\cline { 2 - 3 } & $\begin{array}{c}\text { 4-OHT - } \\
\text { ERo }\end{array}$ & $\begin{array}{c}\text { 1,4-Naphthalenedione-2-ethyl-3- } \\
\text { hydroxy - ERo }\end{array}$ \\
\hline Interaksi Van der Waals (VdW) & $-48,78$ & $-19,58$ \\
Energi Elektrostatik (EEL) & $-27,81$ & 135,66 \\
Kontribusi Elektrostatik terhadap Energi Bebas & 26,01 & $-122,11$ \\
Solvasi (EGB) & & $-2,88$ \\
Kontribusi Non-polar terhadap Energi Bebas Solvasi & $-7,30$ & 116,07 \\
(ESURF) & $-76,58$ & $-124,99$ \\
$\Delta \mathrm{G}_{\text {gas }}$ (VdW + EEL) & 18,71 & $-8,92$ \\
$\Delta \mathrm{G}_{\text {solv }}$ (EGB + ESURF) & $-57,88$ & \\
$\Delta \mathrm{G}_{\text {TOTAL }}$ (VdW + EEL + EGB + ESURF) & & \\
\hline
\end{tabular}

Berdasarkan Tabel 7, menunjukkan bahwa kompleks 4-OHT - ER $\alpha$ memiliki nilai energi bebas ikatan total $\left(\Delta \mathrm{G}_{\mathrm{TOTAL}}\right)$ yang lebih rendah dibandingkan dengan sistem 1,4-naphthalenedione-2-ethyl-3-hydroxy-ER $\alpha$, dimana interaksi Van der Waals (VdW) memberikan kontribusi yang lebih besar daripada energi elektrostatik (EEL). Hal ini menunjukkan bahwa interaksi Van der Waals (VdW) merupakan komponen energi yang paling besar memberikan pengaruhnya terhadap sistem. Kontribusi interaksi Van der Waals (VdW) yang besar terhadap sistem menunjukkan bahwa residu asam amino penyusun kantung aktif protein ER $\alpha$ didominasi oleh residu yang bersifat hidrofobik. Nilai total energi bebas ikatan $(\Delta \mathrm{G})$ pada sistem 4-OHT - ER $\alpha$ yang lebih rendah $(-57,88 \mathrm{kkal} / \mathrm{mol})$ menunjukkan bahwa tingkat afinitas 4-OHT terhadap ERa lebih baik dibandingkan dengan 1,4-naphthalenedione2-ethyl-3-hydroxy dengan nilai total $\Delta \mathrm{G}$ sebesar $-8,92 \mathrm{kkal} / \mathrm{mol}$. Hal ini menunjukkan bahwa senyawa 4-OHT diprediksi lebih poten sebagai obat antikanker payudara daripada senyawa 1,4-naphthalenedione-2-ethyl-3hydroxy. 


\section{KESIMPULAN}

Berdasarkan hasil screening dan proses simulasi penambatan molekul serta dinamika molekular menunjukkan bahwa senyawa 1,4-naphthalenedione-2-ethyl-3-hydroxy dapat berikatan dan mempunyai interaksi yang stabil terhadap reseptor COX-1 (antiinflamasi) dan ER $\alpha$ (antikanker payudara), namun lebih selektif terhadap reseptor COX-1. Hal ini menunjukkan bahwa tingkat afinitas 1,4-naphthalenedione-2-ethyl-3-hydroxy terhadap reseptor COX-1 diprediksi lebih baik dan lebih poten sebagai antiinflamasi dibandingan antikanker payudara.

\section{UCAPAN TERIMA KASIH}

Peneliti ucapkan terima kasih kepada LPPM Universitas Perjuangan Tasikmalaya atas Hibah Penelitian Dosen Pemula Tahun 2020 dan Laboratorium Riset Bioteknologi Molekuler dan Bioinformatika Universitas Padjadjaran atas ijin pemakaian Lisensi Amber Ver. 16.00.

\section{DAFTAR PUSTAKA}

Adriani, 2018. Prediksi Senyawa Bioaktif dari Tanaman Sanrego (Lunasia Amara Blanco) Sebagai Inhibitor Enzim Siklooksigenase-2 (COX-2) Melalui Pendekatan Molecular Docking. Jurnal Ilmiah Pena 1(1), 6-11.

Bassolé, I. H. N., and Juliani, H. R., 2012. Essential Oils in Combination and Their Antimicrobial Properties. Molecules 17(4), 3989-4006. doi: 10.3390/molecules17043989.

Bayala, B., Bassole, I. H. N., Scifo, R., Gnoula, C., Morel, L., Lobaccaro, J. M. A., and Simpore, J., 2014. Anticancer Activity of Essential Oils and Their Chemical Components - A review. American Journal of Cancer Research 4(6), 591-607. ISSN: 2156-6976.

Bray, F., Ferlay, J., Soerjomataram I., Siegel, RL., Torre, LA., Jemal, A. 2018. Global cancer statistics 2018: GLOBOCAN estimates of incidence and mortality worldwide for 36 cancers in 185 countries. CA: A Cancer Journal for Clinicians 68(6), 394-424.

Case, D.A., Babin, V., Berryman J.T., and Ana Bets, R.M., 2014. AMBER 14 Reference Manual. San Francisco: University of California.

Dermawan, D., Sumirtanurdin, R., and Dewantisari, D., 2019. Molecular Dynamics Simulation of Estrogen Receptor Alpha Against Andrografolid as Anti Breast Cancer Simulasi Dinamika Molekular Reseptor Estrogen Alfa dengan Andrografolid sebagai Antikanker Payudara. Indonesian Journal of Pharmaceutical Science and Technology 6(2), 65-76. doi: 10.24198/ijpst.v6i2.18168.

Dhyantari, D., 2015. Efek Antiinflamasi Dari Ekstrak Glukosamin Ceker Ayam Pada Tikus Wistar Jantan Yang Diinduksi Karagenan. The Use Chicken Foot Extraction as the Source of Glucosamine as Anti-Accute Inflamation Agent by In Vivo. Jurnal Pangan dan Agroindustri 3(3), 888-895.

Fuhrmann, J., Rurainski, A., Lenhof, HP., Neumann, D. 2010. A new Lamarckian genetic algorithm for flexible ligand-receptor docking. Journal of Computational Chemstry 31(9), 1911-8. doi: 10.1002/jcc.21478. PMID: 20082382.

Harvey, R. A. \& Champe, P.C. (2013). Farmakologi Ulasan Bergambar, Edisi 4. Kedokteran EGC. Jakarta.

Kilo, A. La, Aman, L. O., Sabihi, I., and Kilo, J. La., 2019. Study of Potential of 1-N-Substituted Pyrazoline Analogues of Thiosemicarbazones as Antiamoebic Agent using In Silico Screening. Indonesian Journal of Chemical Research 7(1), 9-24. doi: 10.30598//ijcr.2019.7-akr.

Liju, V. B., Jeena, K., and Kuttan, R., 2011. An Evaluation of Antioxidant, Anti-Inflammatory, and Antinociceptive Activities of Essential Oil from Curcuma longa L. Indian Journal of Pharmacology 43(5), 526-531. doi: 10.4103/0253-7613.84961.

Mardianingrum, R., Bachtiar, K.R., Nofriyaldi, Ali, and Fadilah, N.N., 2019. Uji Antipiretik Minyak Atsiri Dan Ekstrak Metanol Rimpang Bangle (Zingiber Purpureum R.) pada Mencit Jantan Galur Swiss Webster. Prosiding Seminar Nasional. ISBN: 978-602-5793-65-3, 92-97.

Mardianingrum, R., Yusuf, M., Hariono, M., Gazzali, A., and Muchtaridi, M., 2020. $\alpha$-Mangostin and Its Derivatives Against Estrogen Receptor Alpha. Journal of Biomolecular Structure and Dynamics, 1-14. doi: 10.1080/07391102.2020.1841031.

Muchtaridi, M., Yusuf, M., Diantini, A., Choi, S.B., Al-Najjar, B.O., Manurung, J.V., Subarnas, A., Achmad, T.H., Wardhani, S.R., and Wahab, H.A., 2014. Potential Activity of Fevicordin-A from Phaleria macrocarpa (Scheff) Boerl. Seeds as Estrogen Receptor Antagonist Based on Cytotoxicity and Molecular Modelling Studies. International Journal of Molecular Science 15(5), 7225-7249. doi: 10.1186/s13065-016$0169-9$.

Ningsih, I. Y., 2016. Studi Etnofarmasi Penggunaan Tumbuhan Obat Oleh Suku Tengger Di Kabupaten Lumajang 
Dan Malang, Jawa Timur. PHARMACY: Pharmaceutical Journal of Indonesia, 13(1), 10-20.

Puratchikody, A., Sriram, D., Umamaheswari, A., and Irfan, N., 2016. 3D Structural Interactions and Quantitative Structural Toxicity Studies of Tyrosine Derivatives Intended for Safe Potent Inflammation Treatment. Chemistry Central Journal 10(24), 1-19. doi: 10.1186/s13065-016-0169-9.

Roe, DR. and Cheatham III, TE. 2013. PTRAJ and CPPTRAJ: software for processing and analysis of molecular dynamics trajectory data. Journal of Chemical Theory and Computation 9(7), 3084-3095. doi: $10.1021 / \mathrm{ct} 400341 \mathrm{p}$.

Ruswanto. 2015. Molecular Docking Empat Turunan Isonicotinohydrazide pada Myco bacterium Tuberculosis Enoyl-Acyl Carrier Protein Reductase (InhA). Jurnal Kesehatan Bakti Tunas Husada 13(1), 135-141.

Ruswanto, R., Mardianingrum, R., Siswandono, S., and Kesuma, D., 2020. Reverse Docking, Molecular Docking, Absorption, Distribution, and Toxicity Prediction of Artemisinin as an Anti-Diabetic Candidate. Molekul 15(2), 88-96. doi: 10.20884/1.jm.2020.15.2.579.

Salomon-Ferrer, D.A. Case, R.C. Walker. 2013. An overview of the Amber biomolecular simulation package. Wiley Interdisciplinary Reviews: Computational Molecular Science 3, 198-210.

Sobolewski, C., Cerella, C., Dicato, M., Ghibelli, L., and Diederich, M., 2010. The Role of Cyclooxygenase-2 in Cell Proliferation and Cell Death in Human Malignancies. International Journal of Cell Biology 10, 1-21. doi: 10.1155/2010/215158.

Supriyatna, Febriyanti, R., Dewanto, Wijaya, I., and Ferdiansyah, F., 2015. Fitoterapi Sistem Organ: Pandangan Dunia Barat terhadap Obat Herbal Global, Edisi 2. CV. Budi Utama, Yogyakarta.

Syahputra, G., Ambarsari, L., and Sumaryada, T., 2014. Simulasi Docking Kurkumin Enol, Bismetoksikurkumin Dan Analognya Sebagai Inhibitor Enzim12-Lipoksigenase. Jurnal Biofisika 10(1), 55-67.

Tambunan, Friend, U.S., Amri, N., and Parikesit, A.A., 2012. In Silico Design of Cyclic Peptides as Influenza Virus, a Subtype H1N1 Neuraminidase Inhibitor. African Journal of Biotechnology 11(52), 11474-11491. doi: 10.5897/AJB11.4094.

Thaweboon, S., Taweboon, B., and Kaypetch, R., 2018. Antifungal, Anti-Inflammatory and Cytotoxic Effects of Zingiber cassumunar Gel. Key Engineering Materials 773, 360-364. doi: 10.4028/www.scientific.net/KEM.773.360.

Trott O \& Olson A. (2010). Autodock Vina: Improving The Speed And Accuracy Of Docking With A New Scoring Function, Efficient Optimization And Multi threading. Journal of Computational Chemistry 31, 455-461.

Wang, Y., You, C. X., Yang, K., Wu, Y., Chen, R., Zhang, W. J., and Han, J., 2015. Bioactivity of Essential Oil of Zingiber purpureum Rhizomes and Its Main Compounds against Two Stored Product Insects. Journal of Economic Entomology 108(3), 925-932. doi: 10.1093/jee/tov030. 